\title{
Validated cleaner: the cuculid bird Crotophaga ani picks ticks and pecks at sores of capybaras in southeastern Brazil
}

\author{
Ivan Sazima ${ }^{1}$ \\ ${ }^{I}$ Departamento de Zoologia e Museu de História Natural, Universidade Estadual de Campinas - UNICAMP, \\ CP 6109, CEP 13083-970 Campinas, São Paulo, Brazil \\ ${ }^{2}$ Corresponding author: Ivan Sazima, e-mail: isazima@gmail.com,www.unicamp.br
}

Sazima, I. Validated cleaner: the cuculid bird Crotophaga ani picks ticks and pecks at sores of capybaras in southeastern Brazil. Biota Neotrop., vol. 8, no. 1, Jan./Mar. 2008. Available from: <http://www.biotaneotropica. org.br/v8n1/pt/abstract?short-communication+bn00308012008>.

\begin{abstract}
Information on the role of smooth-billed anis (Crotophaga ani) as tick-pickers on mammals remains controversial. I record here these birds removing ticks and pecking at wounds of capybaras (Hydrochoerus hydrochaeris) in a small reserve at Campinas, São Paulo, southeastern Brazil. The birds inspected the mammals' skin, both in places with and without hair. The hair was parted with bill movements, and ticks were removed by vigorous pulling. The birds also pecked at open or healing sores, from which they extracted small portions of blood clots and dead tissue. The capybaras appeared oblivious to the birds' activity. Even in the case that the cleaning behaviour is restricted to some bird individuals and populations, or places and periods, this record validates the notion that smooth-billed anis removes ticks from herbivorous mammals.
\end{abstract}

Keywords: bird-mammal symbiosis, tick-removing, cleaning behaviour, Hydrochoerus.

Sazima, I. Limpador confirmado: a ave Cuculídea Crotophaga ani cata carrapatos e bica ferimentos em capivaras no sudeste do Brasil. Biota Neotrop., vol. 8, no. 1, jan./mar. 2008. Disponível em: <http://www. biotaneotropica.org.br/v8n1/pt/abstract?short-communication+bn00308012008>.

Resumo: As informações sobre a função de anus-pretos (Crotophaga ani) como catadores de carrapatos em mamíferos permanecem controversas. Registro aqui estas aves removendo carrapatos e bicando ferimentos de capivaras (Hydrochoerus hydrochaeris) numa pequena reserva em Campinas, estado de São Paulo. As aves inspecionavam a pele dos mamíferos, em locais com e sem pêlos. Os pêlos eram afastados com movimentos do bico e os carrapatos maiores eram retirados com puxadas vigorosas. As aves também bicavam ferimentos abertos ou em cicatrização, dos quais retiravam pequenas porções de sangue coagulado e tecido morto. As capivaras pareciam indiferentes à atividade das aves. Ainda que este caso de comportamento de limpeza possa estar restrito a alguns indivíduos e populações, ou locais e períodos, o presente registro confirma a noção de anus-pretos removerem carrapatos de mamíferos herbívoros.

Palavras-chave: simbiose ave-mamífero, remoção de carrapatos, comportamento de limpeza, Hydrochoerus. 


\section{Introduction}

The tick-picking role of the mostly insectivorous smooth-billed ani (Crotophaga ani, Cuculidae) is a controversial issue in the scientific and popular literature. The notion that anis are tick-pickers on cattle is illustrated and commented upon by von Ihering (1946) who compares the tick-removing role of anis to those of the yellowheaded caracara (Milvago chimachima), a falconid well known for its tick-picking on cattle and other herbivorous mammals (Sazima 2007). Ticks were found in one out of 98 C. ani individuals sampled in Colombia, which, however, might be engorged females that fell on the ground for reproduction (Köster 1971). In Spanish, this ani species is called "garrapatero", which means tickbird (Payne 1997). A discussion on the presumed tick-removing role of the smooth-billed ani is found in Sick (1997), based on his personal observations and findings of other authors. Sick (1997) concludes that anis are not tick-eaters at all, but instead they capitalise on insects that dwell in the vegetation and are stirred up by grazing cattle and other large herbivorous mammals. Nevertheless, he admits that some $C$. ani individuals or populations may well feed on ticks without, however, giving further details on how these ticks would be obtained by the birds (Sick 1997).

In an overview of Brazilian tick-removing birds (Sazima 2007) I report on a $C$. ani individual pulling a tick from the leg of a capybara (Hydrochoerus hydrochaeris) in southeastern Brazil. In the discussion, I regard this single record as "another fortuitous instance of tick-picking" (Sazima 2007). Here I report on a group of $C$. ani removing ticks and pecking at sores of capybaras, and thus validate this cuculid as a "cleaning" bird. Additionally, I note that some biological phenomena appear to be restricted to certain conditions and should not immediately be dismissed as popular or even scientific knowledge.

\section{Material and Methods}

The record was made at the reserve "Parque Ecológico Prof. Hermógenes Freitas Leitão Filho" in Campinas, São Paulo state, southeastern Brazil, on 08 August 2007 at a secluded place on the margin of the lake ( $22^{\circ} 48.643$ ' $S$ and $47^{\circ} 04.504^{\prime} \mathrm{W}$ ) that is the core of the reserve. The capybaras were the same pair recorded to interact with yellow-headed caracaras about two months earlier (Sazima 2007). The behaviour of the anis and the capybaras was first assessed with naked eye at a distance of about $15 \mathrm{~m}$, and then observed through binoculars and a $300 \mathrm{~mm}$ telephoto lens. "Ad libitum" and "behaviour" sampling rules (Martin \& Bateson 1986) were used throughout the observational session, which lasted 48 minutes (1540-1628 hours of the austral winter). A series of digital photographs was taken as vouchers, a few of the most representative presented here. Additionally, the photographs were used for further analysis and description of the birds' and mammals' behaviour.

\section{Results}

When I reached the capybaras' place the anis were already perched on, and on the vegetation or the ground around, their two resting clients (Figure 1a). Thus, I have no idea of the time and circumstances the birds began to clean the capybaras. Nevertheless, the anis were still very active inspecting the capybaras' haired or hairless skin as well as healing and open sores, and remained with their clients for additional $48 \mathrm{~min}$. I counted seven birds in the attending group, two to three of them working perched on the capybaras and additional one to two individuals worked while on the ground (Figures 1a, b, and $2 \mathrm{c}$ ). The remaining birds were either foraging on the ground or sunning themselves on the vegetation.
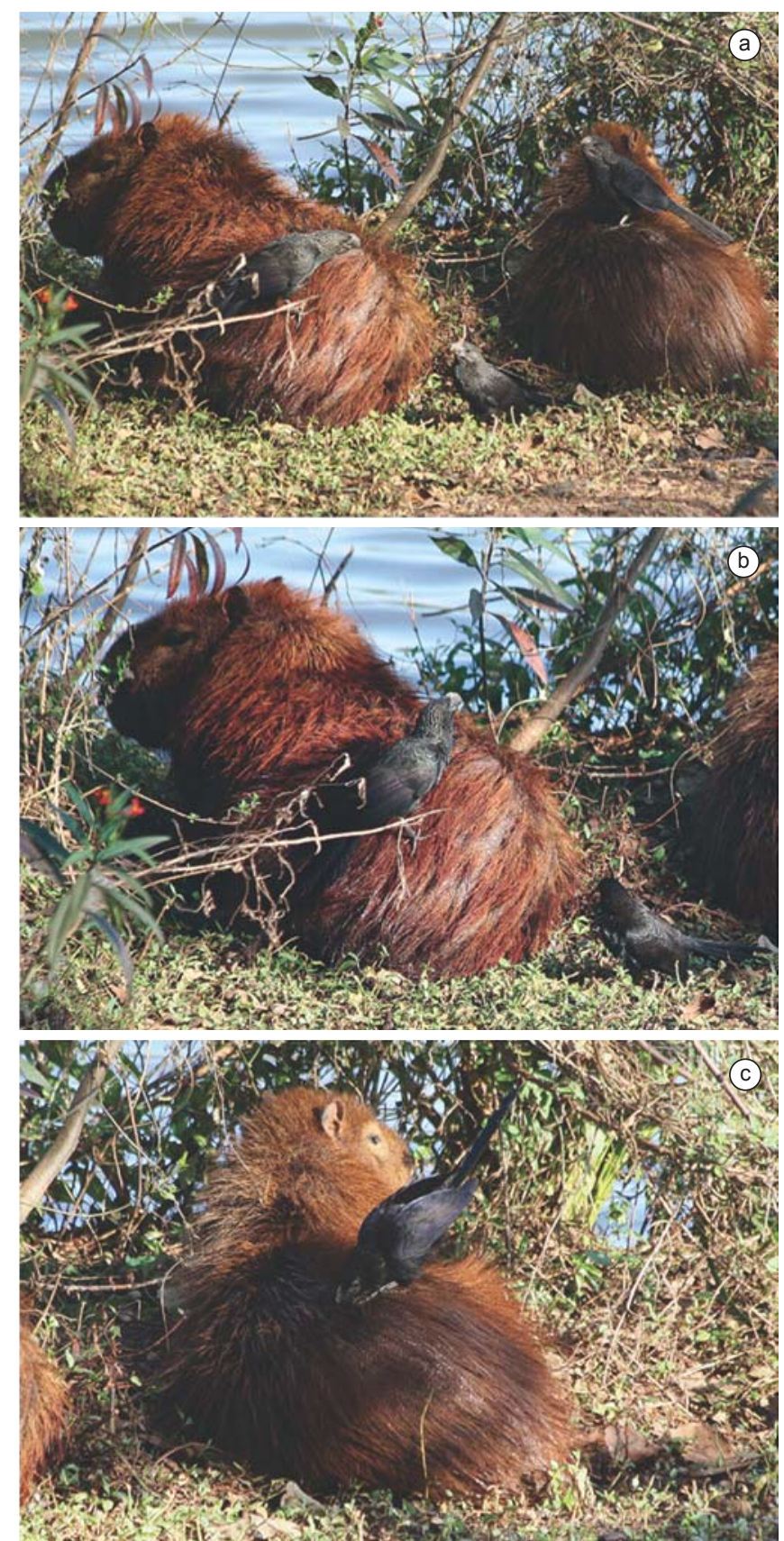

Figure 1. A male (on the left) and a female capybara (Hydrochoerus hydrochaeris) at rest and attended by smooth-billed anis (Crotophaga ani) at a lake margin in Campinas, São Paulo, southeastern Brazil (a) - the bird on the left inspects a tick on the male's back; the same ani individual swallows the tick it was inspecting (b); another ani individual vigorously pulls out a tick it found on the back of the female (c) - note the bird's posture while removing the tick.

Figura 1. Um macho (à esquerda) e uma fêmea de capivara (Hydrochoerus hydrochaeris) sendo atendidas por anus-pretos (Crotophaga ani) na margem de um lago em Campinas, São Paulo (a) - a ave à esquerda inspeciona um carrapato no dorso do macho; o mesmo indivíduo engole o carrapato que estivera inspecionando (b); um outro indivíduo de anu puxa vigorosamente um carrapato que encontrou no dorso da fêmea (c) - note a postura da ave enquanto remove o carrapato.

The anis inspected the capybaras thoroughly, parting the hair of their clients with their bills (Figure 2b). Most of the ticks removed from the capybaras by the anis were medium-sized (about $5 \mathrm{~mm}$ ) and the birds have to put a considerable effort to pick the ticks (Figure 1c). 

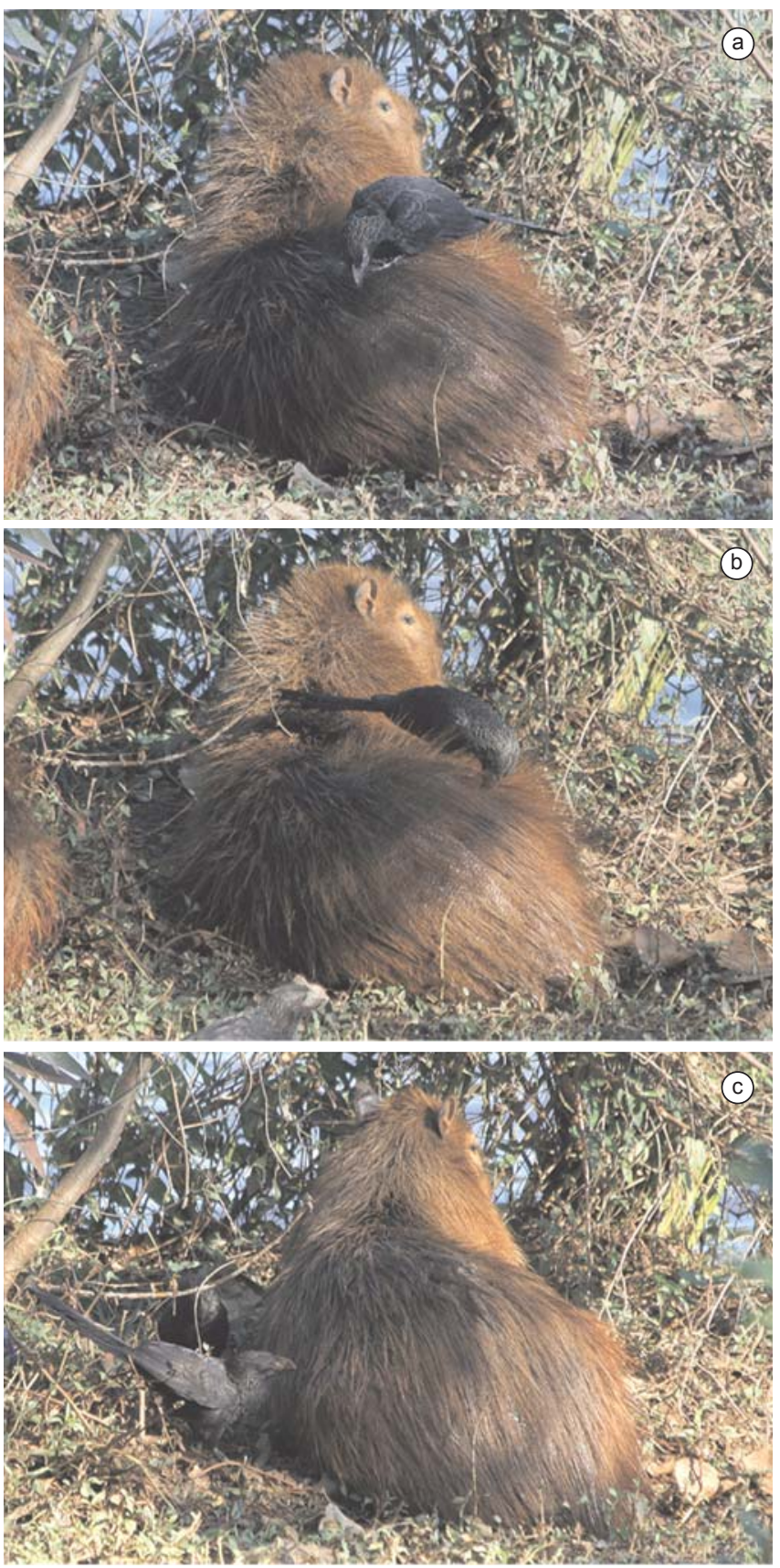

Figure 2. A smooth-billed ani (Crotophaga ani) inspects a healing wound on the back of the capybara female (a); another ani individual inspects the flank of the female (b) - note that the hair is parted with the bird's bill; an ani on the ground pecks at a small open wound on the female's flank (c).

Figura 2. Um anu-preto (Crotophaga ani) inspeciona um ferimento em cicatrização no dorso da capivara fêmea (a); outro indivíduo inspeciona o flanco da fêmea (b) - note que o pêlo é afastado pelo bico da ave; um anu no chão bica um pequeno ferimento recente no flanco da fêmea (c).

While removing a firmly attached tick, an ani adopted a posture characterised by its body oblique to the capybara's own, its feet close to the head presumably to increase its strength and to gain a lever effect. Likely to keep its balance during the pulling effort, the bird's wings were slightly open and kept above the body (Figure 1c). When a tick was removed the bird promptly swallowed its prey (Figure 1b). This latter action was so fleeting that I was able to photograph it adequately twice. Ticks smaller than $5 \mathrm{~mm}$ (even if hard to identify as such from a distance) or those apparently unattached or loosely attached were taken with lesser effort.

The cleaning anis inspected open and healing sores as well (Figure 2a), from which they removed small pieces of blood clots and necrotic tissue. While pecking at an open wound, an ani would stain its bill with congealed blood (Figure 2c). The capybaras hardly reacted to this sore-pecking, and remained at rest with an occasional and slight movement of head towards the cleaning bird. Most of the time, however, the capybaras seemed unperturbed by the birds on their bodies.

Besides the cleaning services, the anis occasionally caught unidentified insects that happened to move or to end, after a jump or flight, on the capybaras' bodies. When the cleaning session ended, two anis remained a few minutes sunning themselves perched on the male capybara's back. One bird took a bath in a small puddle with clean water, and the remaining birds perched on the vegetation, either sunning themselves or allopreening (preening each other, see Sick 1997, Quinn \& Startek-Foote 2000).

\section{Discussion}

To the best of my knowledge, this is the first substantiated record of smooth-billed anis acting as tick-pickers and sore-peckers on herbivorous mammals. In a recent overview of tick-removing birds in Brazil (Sazima 2007) I regarded this ani species as a fortuitous or very occasional tick-picker. The present record changes the situation, since the anis were undoubtedly engaged in so called cleaning behaviour. Cleaning by birds involves removal of parasites, as well as pecking at sores to remove necrotic portions of tissue (see Sazima 2007). Since the anis were recorded doing so, they may be confidently added to the list of cleaner birds in the Neotropics. Thus, the widely disregarded notion that the smooth-billed ani is a tick-picker (see von Ihering 1946, Rosenberg et al. 1990, Payne 1997, Sick 1997, Quinn \& Startek-Foote 2000, for discussion) is here validated as a real biological role, however rare it may be.

A new piece of information is that anis picks blood clot and necrotic tissue from open and healing wounds. In this respect, their behaviour is similar to those of the giant cowbird (Molothrus oryzivorus) and the yellow-headed caracara (Milvago chimachima), both described and illustrated in Sazima (2007). The parting-hair technique is similar to that the smooth-billed ani uses while foraging for insects in the vegetation, as the bird deflects grass leaves with its bill (Quinn \& Startek-Foote 2000). Thus, a technique employed while searching for prey among grass - likely an "old" behaviour - was adjusted to forage on the relatively long-haired capybaras. In this way, the behaviour of deflecting leaves with the bill may be regarded as a preadaptation to search for food on haired mammals. As for the two broad ecological categories recently proposed for Brazilian bird cleaners (Sazima, 2007) the smooth-billed anis would fit into the category of largely insectivorous, widely foraging small to large birds that dwell in the open and that associate with capybaras and/or livestock.

The anis' cleaning behaviour notwithstanding, their capybaras clients seemed mostly oblivious to their activity. This contrasts with the capybaras' behaviour while attended by larger cleaners like the yellow-headed caracara (Milvago chimachima) in which case these mammals adopt "inviting" postures, and react promptly and sometimes vigorously to the likely dolorous pecking at their sores by the bird of prey (Macdonald 1981, Tomazzoni et al. 2005, Sazima 2007). The capybaras remaining apparently unperturbed with the anis' cleaning activity may be due to the small size of the birds, as a similar reaction is reported for the cleaning activity of the giant cowbird (Molothrus oryzivorus) on the same mammal clients (Sazima 2007). 
Additionally, the anis were able to tackle with medium-sized ticks only, which likely caused minor or no pain to the clients when pulled out. Thus, the smooth-billed anis would belong into the category of bird cleaners such as scrub-jays (Aphelocoma californica and A. coerulescens) while cleaning mule and white-tailed deer (Odocoileus hemionus and $O$. virginianus), as these hoofed mammals also seem unperturbed with the birds' activity on their bodies (e.g., Dixon 1944, Fitzpatrick \& Woolfenden 1996).

The possibility remains that the cleaning role of the smooth-billed ani is a rare event, perhaps restricted to a few individuals, social groups or populations, and/or this is a phenomenon localised in space and time or restricted to particular ecological conditions. The Australian crow Corvus orru displays cleaning behaviour in presence of the introduced Asian bovid Bos javanicus, and this symbiotic relationship could have evolved in a very short time - about 150 years (Bradshaw $\&$ White 2006). Situations perhaps unique are reported for animals other than birds (e.g., Greene 1986, Sazima et al. 2003, Bonaldo et al. 2007, Wetherbee et al. 2007), and thus a field researcher should pay attention to apparently rare behaviours and/or particular ecological situations. The results of such open-minded approach usually bring new insights, ideas, or concepts into the natural history and evolutionary biology research areas (Greene 1986).

\section{Acknowledgments}

To Marlies Sazima for her loving support; Luís Fábio da Silveira, José Carlos Motta Jr., and Corey J.A. Bradshaw for their kindly and promptly sending important references; two anonymous referees for their time and valuable suggestions; the $\mathrm{CNPq}$ for essential financial support.

\section{References}

BONALDO, R.M., KRAJEWSKI, J.P. SAZIMA, C. \& SAZIMA, I. 2007. Dentition damage in parrotfishes feeding on hard surfaces at Fernando de Noronha Archipelago, southwest Atlantic Ocean. Mar. Ecol. Progr. Ser. 342:249-254

BRADSHAW, C.J.A., WHITE, W.H. 2006. Rapid development of cleaning behaviour by Torresian crows Corvus orru on non-native banteng Bos javanicus in northern Australia. J. Avian Biol. 37:409-411.

DIXON, J.S. 1944. California jay picks ticks from mule deer. Condor 46:204.

FITZPATRICK, J. W. \& WOOLFENDEN, G.E. 1996. Florida scrub-jay forages on back of white-tailed deer. Condor 98:422-423.
GREENE, H.W. 1986. Natural history and evolutionary biology. In Predatorprey relationships: perspectives and approaches from the study of lower vertebrates (M.E. Feder \& G.V. Lauder, eds.). The University of Chicago Press, Chicago, p.99-108.

VON IHERING, R. 1946. Da vida dos nossos animais. Rottermund, São Leopoldo.

KÖSTER, F.L. 1971. Zum nistverhalten des ani. Bonn. Zool. Beitr. 22:4-27.

MARTIN, P. \& BATESON, P. 1986. Measuring behaviour, an introductory guide. Cambridge University Press, Cambridge.

MACDONALD, D.W. 1981. Feeding associations between capybaras Hydrochoerus hydrochaeris and some bird species. Ibis 123(3):364-366

PAYNE, R.B. 1997. Family Cuculidae (cuckoos). In Handbook of the birds of the world. Vol. 4. Sandgrouses to cuckoos (J. del Hoyo, A. Elliot \& J. Sargatal, eds.). Lynx Edicions, Barcelona, p.508-607.

QUINN, J. \& STARTEK-FOOTE, J.M. 2000. Smooth-billed ani (Crotophaga ani). In: The birds of North America, No. 539 (A. Poole \& F. Gill, eds). The Birds of North America, Inc. Philadelphia. Online ed. Dois: 10.2173/ bna.539.

ROSENBERG, D.K., WILSON, M.H. \& CRUZ, F. 1990. The distribution and abundance of the smooth-billed ani Crotophaga ani (L.) in the Galápagos Islands, Ecuador. Biol. Conserv. 51: 113-123.

SAZIMA, I. 2007. Unexpected cleaners: black vultures (Coragyps atratus) remove debris, ticks, and peck at sores of capybaras (Hydrochoerus hydrochaeris), with an overview of tick-removing birds in Brazil. Rev. Bras. Ornitol. 15(1):417-426.

SAZIMA, I., SAZIMA, C. \& SILVA-JR., J.M. 2003. The cetacean offal connection: feces and vomits of spinner dolphins as a food source for reef fishes. Bull. Mar. Sci. 72(1):151-160.

SICK, H. 1997. Ornitologia brasileira. Editora Nova Fronteira, Rio de Janeiro.

TOMAZZONI, A. C., PEDÓ, E. \& HARTZ, S.M. 2005. Feeding associations between capybaras Hydrochoerus hydrochaeris (Linnaeus) (Mammalia, Hydrochaeridae) and birds in the Lami Biological Reserve, Porto Alegre, Rio Grande do Sul, Brazil. Rev. Bras. Zool. 22:713-716.

WETHERBEE, B.M., GRUBER, S. \& ROSA, R.S. 2007. Movement patterns of juvenile lemon sharks Negaprion brevirostris within Atol das Rocas, Brazil: a nursery characterized by tidal extremes. Mar. Ecol. Progr. Ser. 343:283-293. 